\title{
Night temperature drop affects the diurnal photosynthetic rhythm of Kalanchoe blossfeldiana
}

\author{
L.M. Mortensen and H.R. Gislerød \\ Department of Plant Sciences, Faculty of Biosciences, The Norwegian University of Life Sciences, Ås, Norway
}

\section{Summary}

Kalanchoe blossfeldiana is a CAM plant. However, it functions like a $\mathrm{C}_{3}$ plant under normal greenhouse conditions with net $\mathrm{CO}_{2}$ uptake during the light period and net $\mathrm{CO}_{2}$ production during the dark period. Stress conditions such as drought induce a change from $\mathrm{C}_{3}$ to CAM metabolism. Dynamic temperature control in greenhouses as a means of saving energy entails a drop in night temperature. The question was whether a night temperature drop would be perceived as a stress signal, causing the plants to switch from $\mathrm{C}_{3}$ to CAM photosynthesis. In the first experiment, the diurnal $\mathrm{CO}_{2}$ exchange rates (CER) of small plant stands of $K$. blossfeldiana were measured with and without a temperature drop during the dark period from about $20^{\circ} \mathrm{C}$ to $6-12^{\circ} \mathrm{C}$ when grown at a photon flux density (PFD) of $220 \mu \mathrm{mol} \mathrm{m}^{-2} \mathrm{~s}^{-1}$ during $16 \mathrm{~h}_{\text {day }}{ }^{-1}$ (8 h dark period). At a constant temperature, CER was relatively constant throughout the photoperiod. A drop to $12^{\circ} \mathrm{C}$ during the night caused a strong diurnal rhythm with high CER during the first and last hours of the light period and a $75 \%$ decrease in CER in the middle of the day as compared to the first hours of the light period. A drop to $6^{\circ} \mathrm{C}$ resulted in net photosynthesis reaching zero at midday the following day. Low night temperature caused a change from negative to positive CER values during the night, demonstrating a CAM metabolism. In a second experiment, CER was measured at light conditions simulating clear days in a greenhouse in late spring $\left(0-1100 \mu \mathrm{mol} \mathrm{m} \mathrm{m}^{-2} \mathrm{~s}^{-1}\right)$. A drop to $7^{\circ} \mathrm{C}$ during the night decreased CER by about $50 \%$ from morning to midday, before it then started increasing again. By gradually increasing the diurnal minimum night temperature, the midday CER decrease eventually disappeared. Regression analysis showed a close relationship between the temperature drop and the midday decrease as well as increased CAM metabolism. The response illustrated the genetics of $K$. blossfeldiana, originating in dry, arid conditions in Madagascar where low temperature during the night is a signal for the plant to protect itself against a warm, dry day by closing the stomata. Dynamic temperature control involving a night temperature drop is not recommended for this species due to the negative effect on photosynthesis when the plants change from $C_{3}$ to the less efficient CAM metabolism under greenhouse conditions.

Keywords

CAM, $\mathrm{C}_{3}$, carbon dioxide exchange rate, photon flux density, temperature difference

\section{Significance of this study}

What is already known on this subject?

- It is known that Kalanchoe blossfeldiana functions like $\mathrm{C}_{3}$ plants under normal greenhouse cultivation.

What are the new findings?

- A temperature drop during the night to save energy causes the plants to switch from $\mathrm{C}_{3}$ to CAM photosynthesis, resulting into much lower total photosynthesis.

What is the expected impact on horticulture?

- For this species low night temperature to save energy is not recommended.

\section{Introduction}

Kalanchoe blossfeldiana is a popular ornamental species with a crassulacean acid metabolism (CAM) photosynthetic pathway, deviating from most greenhouse plants that are $\mathrm{C}_{3}$ species (Taybi et al., 1995). CAM plants can be divided into obligate (full CAM plants) and facultative (switch between CAM and $\mathrm{C}_{3}$ photosynthesis) plants, and ornamental CAM species have been shown to belong to both groups (Lee et al., 2006). In facultative plants, drought stress typically induces CAM photosynthesis which rapidly reverts to $\mathrm{C}_{3}$ photosynthesis by watering (Winter and Holtum, 2014). In several experiments with $K$. blossfeldiana, we have always found that the diurnal photosynthesis as well as growth responses to different environmental factors were similar to that of $\mathrm{C}_{3}$ greenhouse plants (Mortensen, 1983, 1994, 2000, 2014). Under non-stress conditions, facultative CAM plants are unlikely to perform CAM photosynthesis. However, stress factors other than drought may cause a switch from $\mathrm{C}_{3}$ to CAM metabolism (Lüttge, 2004; Lee et al., 2006). Today, reducing energy consumption in greenhouses is a major focus. If the industry is to be recognised as environmentally friendly, it must reduce the $\mathrm{CO}_{2}$ emissions that potentially cause global climate change (IPCC, 2013). One means of saving energy is through dynamic temperature control of the greenhouse environment (Körner and Challa, 2003; Lund et al., 2006; Dieleman and Meinen, 2007). In this concept, the greenhouse air is heated by solar radiation/supplementary lighting during the day while the temperature is allowed to decrease without heating during the night. Since greenhouse plants react primarily to the average temperature, diurnal fluctuations can be applied without negatively affecting plant growth and development (De Koning, 1988; Rijsdijk and Vogelezang, 2000; Blanchard and Runkle, 2011). As an important greenhouse crop, energy saving is important in the production of $K$. blossfeldiana. However, the question is if dynamic temperature 
control that allows low night temperature causes a stress inducing CAM metabolism in this species? In such case, reduced light utilisation may be the result. In order to answer this question, the diurnal photosynthesis was followed when small plant stands were exposed to low temperatures during the night.

\section{Materials and methods}

Rooted cuttings of Kalanchoe blossfeldiana 'Alicia' were planted in fertilised peat (Kekkilä, Estonia) in 10 -cm pots. The plants were grown for six weeks at $18-20^{\circ} \mathrm{C}$ under shortday conditions $\left(10 \mathrm{~h} \mathrm{day}^{-1}\right)$ with $100 \mu \mathrm{mol} \mathrm{m}^{-2} \mathrm{~s}^{-1}$ supplementary high pressure sodium light in October-November in a greenhouse at $59^{\circ} \mathrm{N}$. After six weeks (at the stage of visible flower initiation), the plants were moved to the experimental conditions in four chambers to measure carbon dioxide exchange rates (CER).

\section{Chambers for measuring carbon dioxide exchange rates (CER)}

Four chambers with a diameter of $24 \mathrm{~cm}$ and a height of $50 \mathrm{~cm}\left(22.6 \mathrm{dm}^{3}\right.$ volume, floor area $\left.4.52 \mathrm{dm}^{2}\right)$ were made of 6-mm acrylic tubes. A removable lid was placed on top of each chamber. A Resun ACO-001 pump (China) supplied air to the chambers through a plastic tube at a flow rate of 1300 $\mathrm{L} \mathrm{h}^{-1}$ as measured by a flowmeter. The $\mathrm{CO}_{2}$ concentration was measured by an infrared gas analyzer (PP systems, WMA-4 $\mathrm{CO}_{2}$ analyzer, Amesbury, MA, USA). Air sampling was regulated by a solenoid valve relay controller switching between three different channels each minute (AM416 Relay multiplexer, Campbell Scientific Inc., Logan, UT, USA). The $\mathrm{CO}_{2}$ concentration was measured in the inlet and the outlet air from two chambers. Two chambers at a time were measured every other hour. The $\mathrm{CO}_{2}$ exchange rate (CER) was calculated using the following formula: $\left(\mathrm{C}_{\text {in }}-\mathrm{C}_{\text {out }}\right) \times \mathrm{F}$ where $\mathrm{C}_{\text {in }}$ and $\mathrm{C}_{\text {out }}$ were the $\mathrm{CO}_{2}$ concentrations in and out of the chamber, respectively, and $\mathrm{F}$ the flow rate per hour $\left(1300 \mathrm{dm}^{3}\right)$. The chambers were placed in $10 \mathrm{~cm}$ deep water baths. The temperature in the chambers was controlled by a Jumo dTron 316 unit programmed to give a specific diurnal temperature pattern by switching a $200 \mathrm{~W}$ aquarium heater on and off in each water bath. The chambers were placed outdoors, and natural low temperatures ensured adequate cooling. The temperature was measured by copper-constantan thermocouples, and the air humidity by Vaisala HMP 35A sensors. The chambers were shaded from daylight and a $180 \mathrm{~W}$ LED lamp (Type E21, Evolys, Norway) that produces white light was installed at the top of each of the chambers. The light level was controlled by a homemade unit continuously supporting the LED lamps with a defined voltage that controlled the PFD level during the day. By this means, a typical diurnal variation of daylight in a greenhouse during clear days in spring at $60^{\circ} \mathrm{N}$, was supplied to the chambers $(0-1100 \mu \mathrm{mol}$ $\mathrm{m}^{-2} \mathrm{~s}^{-1}$ PFD, Figure 1). The light was measured by a Delta-T Devices PAR sensor (cosine corrected within $\pm 5 \%$ up to $70^{\circ}$ incidence). The $\mathrm{CO}_{2}$ concentration, temperature, relative air humidity and light level were stored as $0.5 \mathrm{~h}$ means by a Campbell CR10X logger with an AM25T thermocouple multiplexer (Campbell Scientific Ltd., England, UK).

\section{Experiment 1: Night temperature drop under constant artificial lighting}

Three plants were placed in each of the four chambers. A PFD of $225 \mu \mathrm{mol} \mathrm{m}{ }^{-2} \mathrm{~s}^{-1}$ was given $16 \mathrm{~h} \mathrm{day}^{-1}$ (correspond-

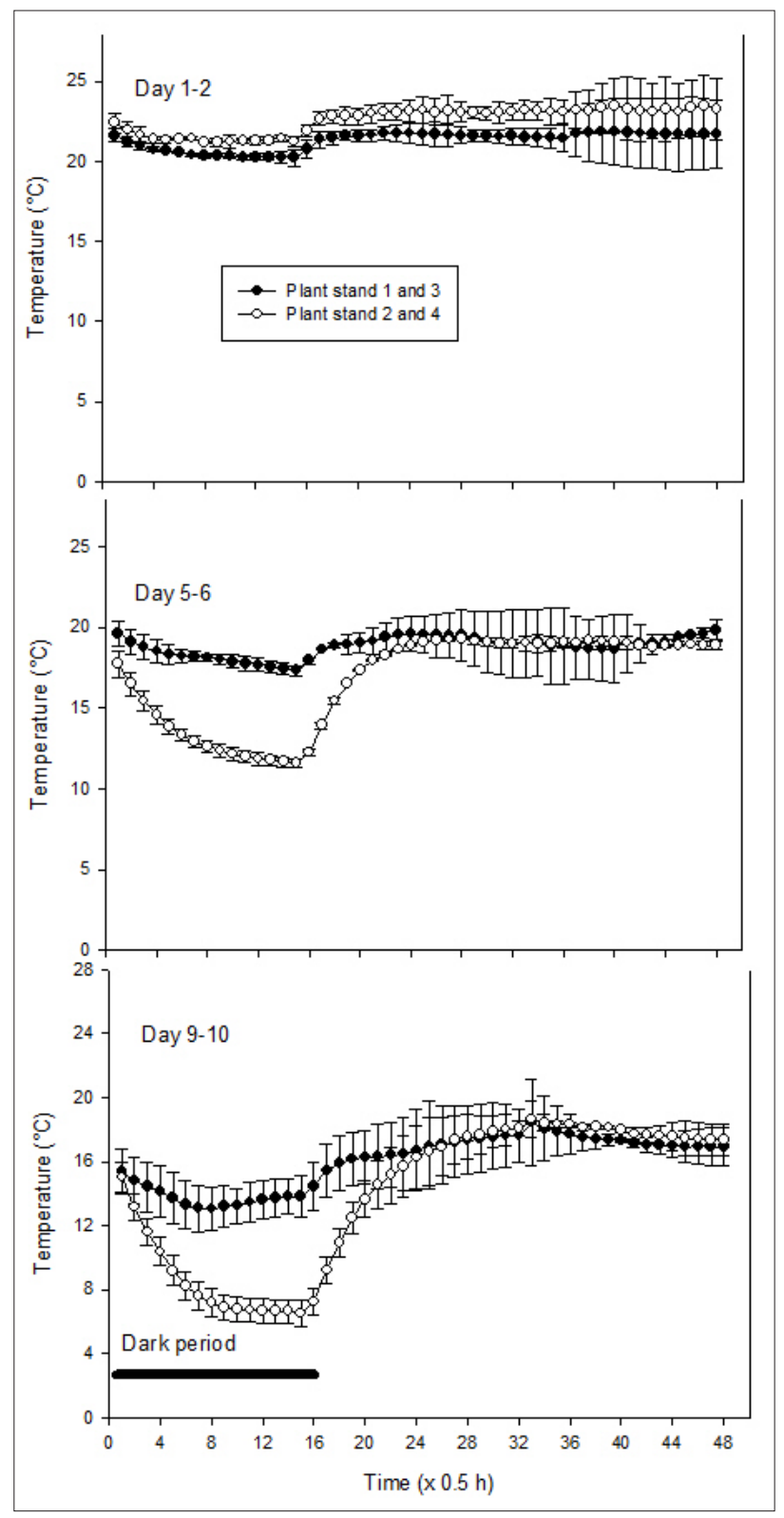

FIGURE 2. The mean diurnal temperature for plant stand 1 and $3( \pm \mathrm{SD}, n=2)$ and for plant stand 2 and $4( \pm \mathrm{SD}, n=2)$, in different time periods in Experiment 1. The 8-h dark period is indicated with a black line.

ing to $13.0 \mathrm{~mol} \mathrm{~m}^{-2}$ day $^{-1} \mathrm{PAR}$ ) in all chambers (Figure 1). A black curtain was used to block out daylight. Chamber 1 and 3 (plant stand 1 and 3) were given the same treatment and Chamber 2 and 4 (plant stand 2 and 4 ) a second treatment. Air with a $\mathrm{CO}_{2}$ concentration of $415 \pm 15 \mathrm{mmol} \mathrm{mol}^{-1}$ was supplied to the chambers. During day 1-2 of the experiment, the temperature was $20-22^{\circ} \mathrm{C}$ during the day and night (Figure 2). During day 5-6, plant stand 2 and 4 were exposed to a night temperature drop to about $12^{\circ} \mathrm{C}$, and, over the following days, the night temperature dropped to a minimum of $6.5^{\circ} \mathrm{C}$ (Figure 2). The night temperature in plant stand 1 and 3 also decreased to some extent, however, to a significantly lesser extent than in the low temperature treatment. The temperature during days 3-4 and 7-8 was used to adjust the plants to a new temperature regime. 


\section{Experiment 2: Temperature drop under simulated daylight conditions}

Three plants were placed in each of the four chambers. A diurnal PFD was established simulating the natural light $(16 \mathrm{~h})$ conditions during clear days in late spring in a greenhouse of up to about $1100 \mu \mathrm{mol} \mathrm{m}^{-2} \mathrm{~s}^{-1}$ (Figure 1). During the normal dark period of eight hours, a constant $34 \mu \mathrm{mol} \mathrm{m}{ }^{-2} \mathrm{~s}^{-1}$ PFD was supplied to eliminate any photoperiodic effect on the photosynthetic rhythm. During day 1-2 of the experiment, the temperature followed the diurnal rhythm of the light level with a minimum temperature of $6^{\circ} \mathrm{C}$ at night and a maximum day temperature of $21-22^{\circ} \mathrm{C}$ (Figure 3). During day 5-6, the temperature dropped to a minimum of $10^{\circ} \mathrm{C}$ in Chamber 2 and 4 (plant stand 2 and 4 ) while Chamber 1 and 3 (plant stand 1 and 3 ) were heated to $21^{\circ} \mathrm{C}$ during the night (Figure 3). During day 7-8, all the chambers were heated during the night. The temperature during day 3-4 was used to adjust the plants to a new temperature regime.

At the end of the experiments, the total leaf dry weight per plant and dry weight and area of five leaves per plant were measured. Since our leaf area meter was broken the leaf area was estimated by taking the outlines of the leaves on paper sheets. The outlines were cut and weighed. The leaf area was then calculated based on the paper sheet weight per $\mathrm{dm}^{2}$. The values were used to calculate total leaf area per plant, and then the total leaf area per chamber (three plants). Regression and correlation analyses were carried out between the temperature drop during the night and the percentage drop in CER from morning until midday, as well as the CER during the night. In addition, the correlation between night CER and percent midday decrease was carried out. SigmaPlot 10.0 (Systat Software Inc.) was used in the regression and correlation analyses as well as in the presentation of graphs.

\section{Results}

\section{Experiment 1: Night temperature drop under constant artificial lighting}

During the first days of the experiment with small diurnal variation in the temperature between day and night, the CER was relatively constant during the day period after a peak during the first two hours of the light period (Figure 4). A negative CER (respiration) dominated during the night.

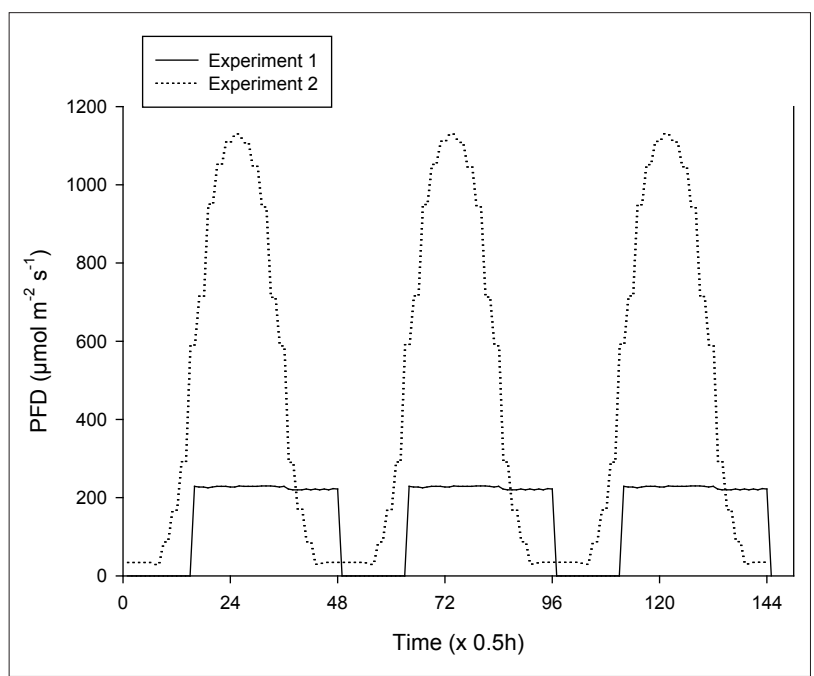

FigurE 1. The diurnal photon flux density (PFD) in Experiment 1 and 2 by means of LED-lamps.
During day 5-6, the night temperature dropped to $12^{\circ} \mathrm{C}$ in plant stand 2 and 4, causing a 75\% decrease in CER from morning until midday. A further drop in night temperature to $6.5^{\circ} \mathrm{C}$ caused midday CER to be close to zero, while CER during the night changed from negative to positive (Figure 4). A drop in night temperature to a minimum of $14-15^{\circ} \mathrm{C}$ also significantly decreased the CER during the middle of the day in plant stand 1 and 3. The CER during the middle of the day $\left(\mathrm{CER}_{\text {min. }}\right)$ relative to the maximum in the morning $\left(\mathrm{CER}_{\text {max }}\right)$ was calculated and correlated with the difference between maximum and minimum temperature during the day and night (temperature drop) (Figure 5). When the day/night temperature difference increased from $1-2^{\circ} \mathrm{C}$ to $13^{\circ} \mathrm{C}$, the CER in the middle of the day, compared with the morning CER, changed from about $80 \%$ to $2 \%$ (Figure 5). At

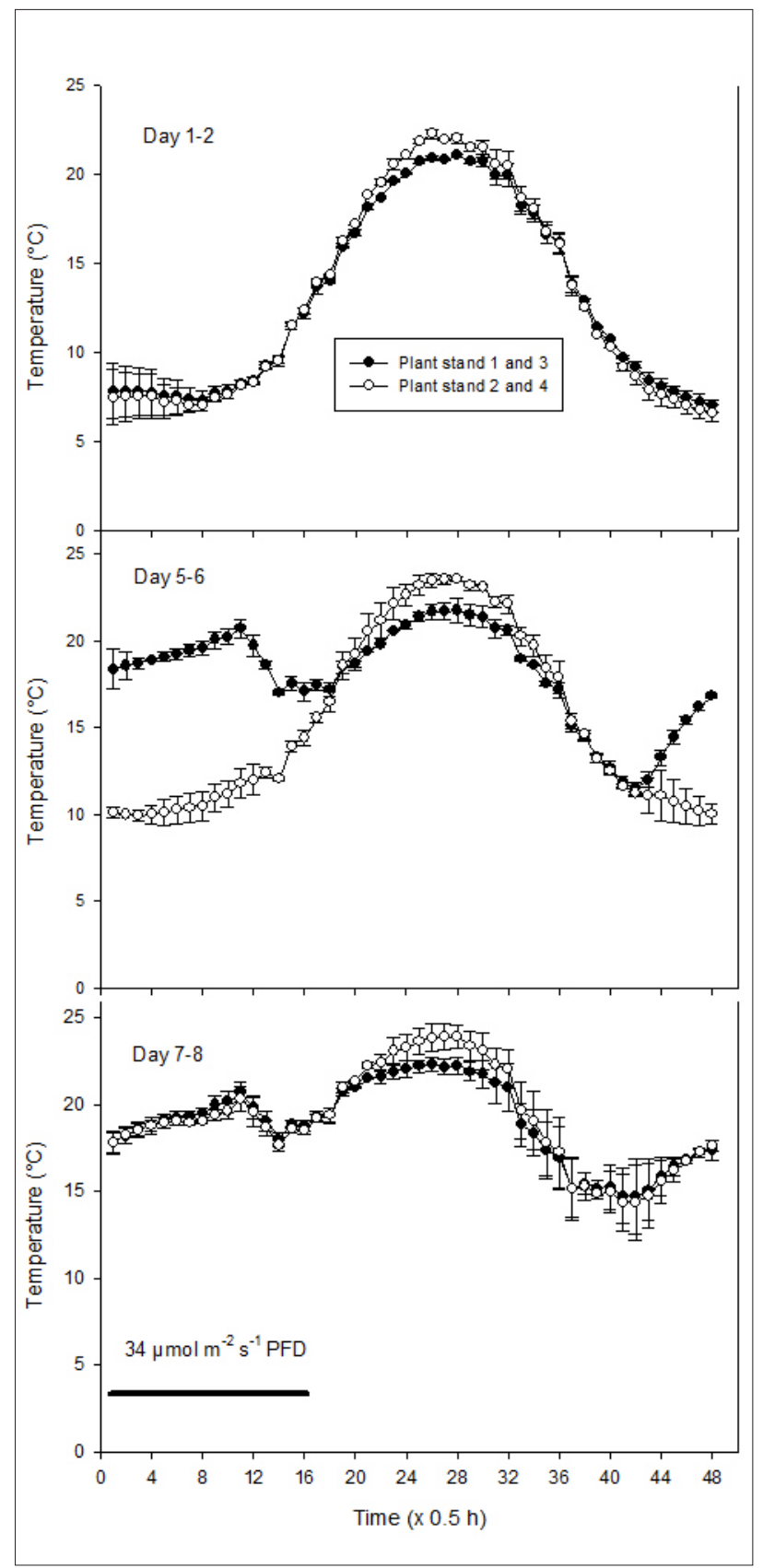

FIGURE 3. The mean diurnal temperature for plant stand 1 and $3( \pm \mathrm{SD}, n=2)$ and for plant stand 2 and $4( \pm \mathrm{SD}, n=2)$, in different time periods in Experiment 2. The 8-h time period of $34 \mu \mathrm{mol} \mathrm{m} \mathrm{m}^{-2} \mathrm{~s}^{-1} \mathrm{PFD}$ is indicated with a black line. 
the same time, the CER proportionally increased during the night from a negative to a positive value (Figure 5). Thus, the CER in darkness increased proportionally with a decrease in the CER in the middle of the day (Figure 5). At the end of the experiment, the mean leaf area of the plant stands in the four chambers was $18.5 \pm 2.3 \mathrm{dm}^{2}( \pm \mathrm{SD}, n=4)$.

\section{Experiment 2: Temperature drop under simulated daylight conditions}

The temperature fluctuated from $6^{\circ} \mathrm{C}$ to $21-22^{\circ} \mathrm{C}$ during the first two days in Experiment 2. The maximum CER was about $30 \mathrm{mmol} \mathrm{CO}_{2} \mathrm{~m}^{-2} \mathrm{~h}^{-1}$ in the morning, with a $50 \%$ decrease at midday before it increased again somewhat (Figure 6). At a minimum temperature of $10^{\circ} \mathrm{C}$ (day 5-6), the CER increased to a maximum of about $50 \mathrm{mmol} \mathrm{CO}_{2} \mathrm{~m}^{-2} \mathrm{~h}^{-1}$, still with a drop in CER at midday in spite of increasing PFD up to $1100 \mu \mathrm{mol} \mathrm{m}{ }^{-2} \mathrm{~s}^{-1}$. By maintaining the night temperature at between 15 and $20^{\circ} \mathrm{C}$ (day 7-8), the CER more or less followed the diurnal PFD level, reaching a maximum of about $90 \mathrm{mmol} \mathrm{CO} \mathrm{m}^{-2} \mathrm{~h}^{-1}$. The CER at night changed from positive to negative as the night temperature increased. It should be noted that the low-level light of $34 \mu \mathrm{mol} \mathrm{m}^{-2} \mathrm{~s}^{-1}$ during the

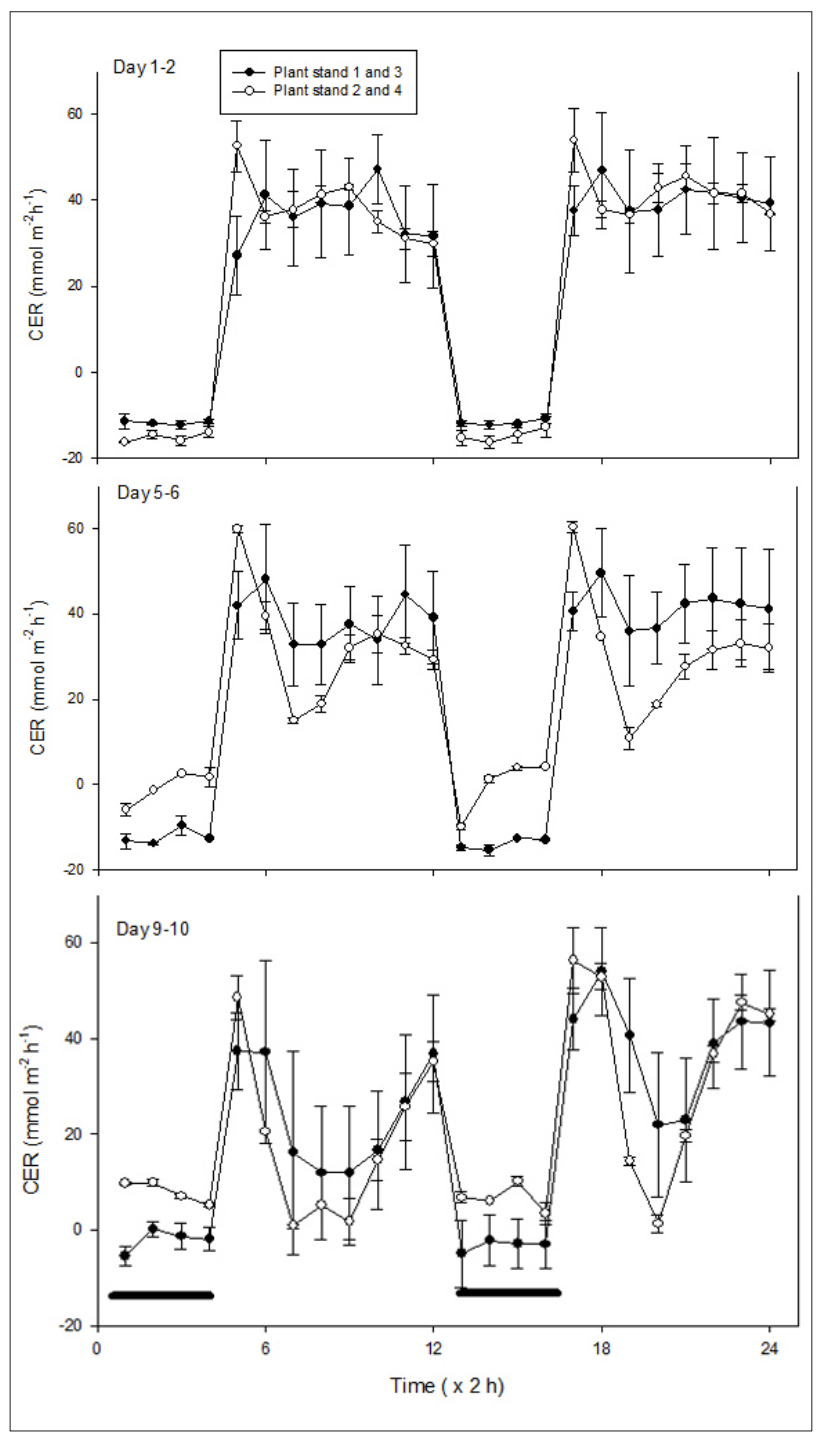

FigurE 4. The mean $\mathrm{CO}_{2}$ exchange rate (CER) for plant stand 1 and $3( \pm$ SD, $n=2)$ and for plant stand 2 and $4( \pm S D, n=2)$, in different time periods in Experiment 1 . The 8-h dark period is indicated with a dark line. night increased the CER to some extent. At the end of the experiment, the mean leaf area of the plant stands in the four chambers was $15.4 \pm 1.4 \mathrm{dm}^{2}( \pm \mathrm{SD}, n=4)$.

\section{Discussion}

As long as the temperature during the day and night remained relatively constant, the diurnal CER was quite similar to that previously measured in $K$. blossfeldiana as well as in roses (Mortensen, 1995, 2014). This reflected a typi-

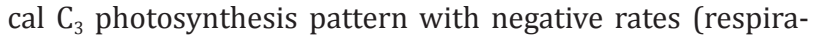
tion) during the dark period and a positive CER depending on the light level during the day. This was found in spite of the recent transferral of the plants from a six-week, shortday treatment to long-day conditions. Based on literature, this species was expected to retain CAM metabolism after

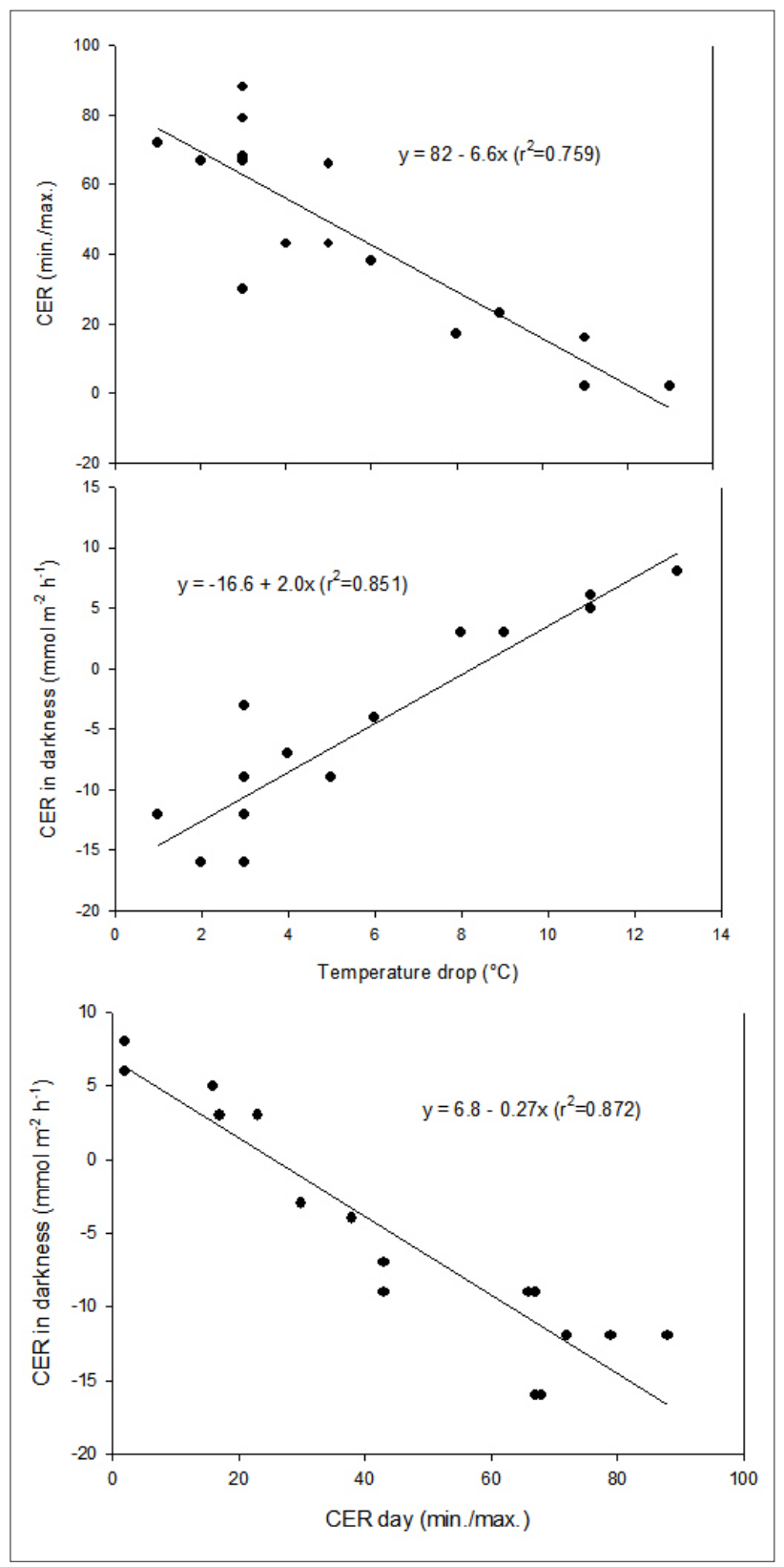

FigurE 5. Correlations between temperature drop $\left({ }^{\circ} \mathrm{C}\right)$ and $\%$ decrease in CER from morning until midday (A), between temperature drop and CER in darkness (B) and between \% decrease in CER from morning until midday and CER in darkness (C) in Experiment 1. 


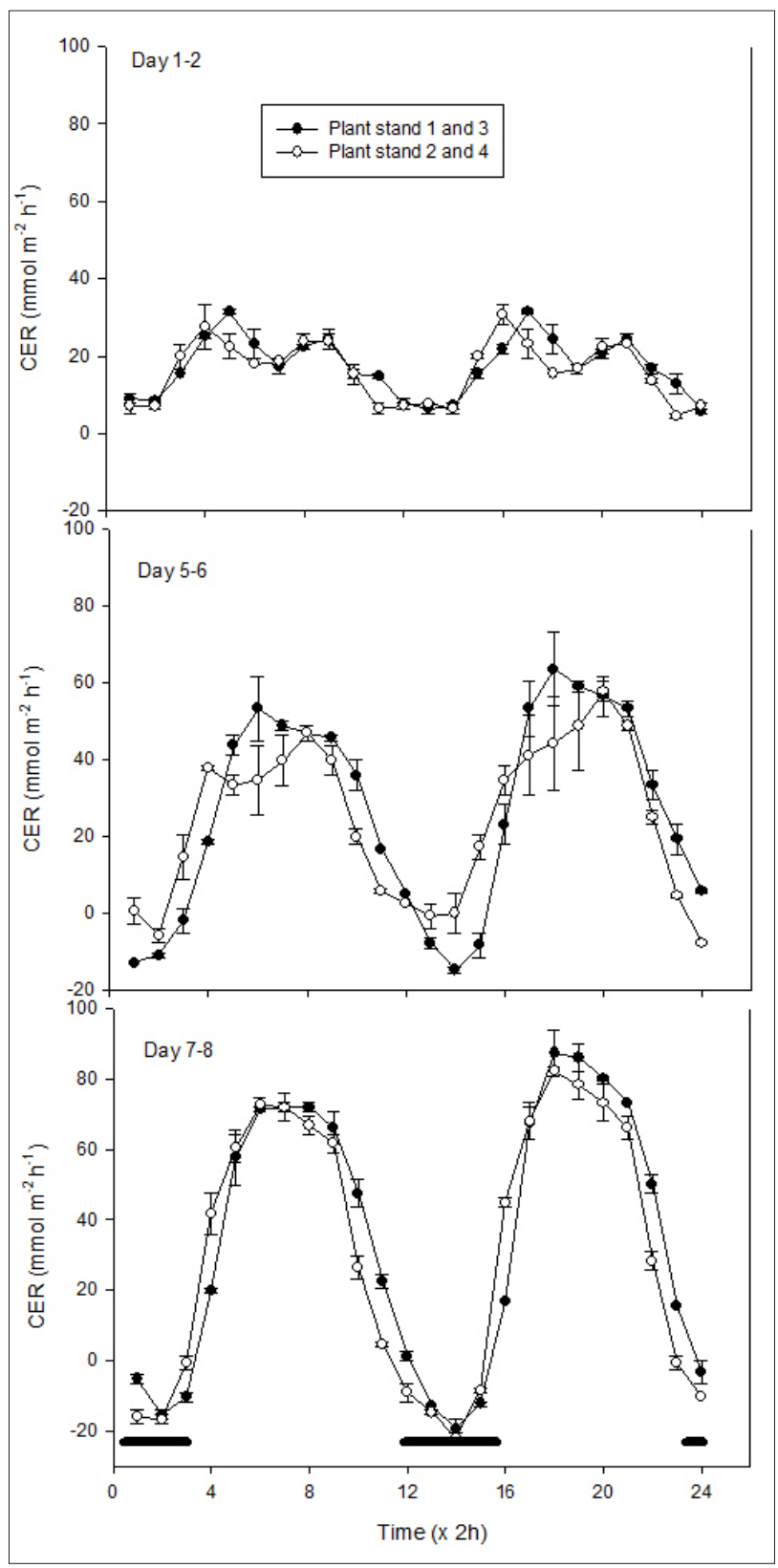

FiguRE 6. The diurnal $\mathrm{CO}_{2}$ exchange rate (CER) as a mean for plant stand 1 and $3( \pm \mathrm{SD}, n=2)$ and as a mean for plant stand 2 and $4( \pm \mathrm{SD}, n=2)$, in different time periods in Experiment 2 . The 8 -h time period of $34 \mu \mathrm{mol} \mathrm{m} \mathrm{m}^{-2} \mathrm{~s}^{-1} \mathrm{PFD}$ is indicated with a black line.

short-day treatment (Queiroz and Brulfert, 1982; Winter and Holtum, 2014). However, a temperature drop during the night adversely changed the typical $\mathrm{C}_{3}$ pattern of photosynthesis. Unlike other greenhouse species such as Argyranthemum frutescens, a temperature drop immediately induced a midday decrease in photosynthesis even at a constant light level (Mortensen and Gislerød, 2016). The midday CER decreased proportionally with the drop in temperature the previous night, reaching close to zero at a night temperature of $6^{\circ} \mathrm{C}$. At the same time, net respiration switched to a significant positive $\mathrm{CO}_{2}$ uptake during the night. CAM can be divided into four distinct phases during a day (Yamori et al., 2014): $\mathrm{CO}_{2}$ uptake via stomata during the night and accumulation of malic acid (phase I), a transition phase with $\mathrm{CO}_{2}$ uptake at dawn when the stomata are open (phase II), decarboxylation of malic acid and re-fixation of $\mathrm{CO}_{2}$ behind closed stomata at midday (phase III) and a transition phase when stomata are open at dusk (phase IV). Thus, we can conclude that typical CAM photosynthesis was a result of the temperature drop at night. According to Yamori et al. (2014), the diurnal photosynthetic pattern in CAM plants as a response to day/night temperature variation has yet to be clarified, although day and night temperature vary considerably in deserts where many CAM plants are found. A temperature drop during the night thus appears to immediately induce a change from $\mathrm{C}_{3}$ to CAM photosynthesis in $K$. blossfeldiana. This may reflect a natural response to the environment of a species that originates in arid regions of Madagascar $\left(15-25^{\circ}\right.$ southern latitude) with large diurnal temperature fluctuations. The surface temperature in a desert at low latitudes may vary $20-30^{\circ} \mathrm{C}$ during the 24 -h cycle, including hot days and cool nights close to zero degrees (Pinker et al., 2007). For CAM plants, a low night temperature therefore signals a hot, dry day when the stomata should be kept closed to avoid water loss. Since this temperature effect is genetically based, the response persists even when it is not necessary under the well-watered conditions of $K$. blossfeldiana in greenhouses.

Rascher et al. (1998) found that a rapid, rather than a slow, temperature change $\left(0.5^{\circ} \mathrm{Ch}^{-1}\right)$ induced a change in the photosynthetic rhythm in Kalanchoe daigremontiana. In the present experiment, the temperature drop was $2-3^{\circ} \mathrm{C} \mathrm{h}^{-1}$ so this may have caused the very strong effect on the diurnal photosynthetic rhythm. If dynamic temperature control is applied for this species, a slow temperature drop may reduce the negative effect on photosynthesis. In practice, this will entail some heating during the night. However, it would be interesting to investigate whether the speed of the drop is more important than the temperature level itself.

In the present study, the CER of about $40 \mathrm{mmol} \mathrm{CO}_{2}$ $\mathrm{m}^{-2} \mathrm{~s}^{-1}$ at constant $225 \mu \mathrm{mol} \mathrm{m}{ }^{-2} \mathrm{~s}^{-1}$ PFD was similar to that measured by Pagter et al. (2013) on single leaves at about $1000 \mu \mathrm{mol} \mathrm{m}{ }^{-2} \mathrm{~s}^{-1}$ in the same species. They also found that two days chilling at $4{ }^{\circ} \mathrm{C}$ decreased the photosynthesis by about $50 \%$, a finding similar to that in the present experiment by abruptly decreasing the temperature from $20^{\circ} \mathrm{C}$ to below $10^{\circ} \mathrm{C}$ during the night. Generally, it can be concluded from the present results that $K$. blossfeldiana is a species that can easily switch from $\mathrm{C}_{3}$ to CAM photosynthesis with a night temperature drop. This will likely result in a considerable decrease in overall photosynthesis and growth, and dynamic temperature control of the greenhouse atmosphere to save energy cannot therefore be recommended.

\section{Acknowledgments}

This study was funded by the Research Council of Norway and the Norwegian Growers Association (project 'VeksthusDynamikk'), which we gratefully acknowledge.

\section{References}

Blanchard, M.G., and Runkle, E.S. (2011). The influence of day and night temperature fluctuations on growth and flowering of annual bedding plants and greenhouse heating cost predictions. HortScience 46, 599-603.

De Koning, A.N.M. (1988). The effect of different day/night temperature regimes on growth, development and yield of glasshouse tomatoes. J. Hortic. Sci. 63, 465-471. https://doi.org/10. 1080/14620316.1988.11515880.

Dieleman, J.E., and Meinen, E. (2007). Interacting effect of temperature integration and light intensity on growth and development of single- 
stemmed cut rose plants. Sci. Hortic. 113, 182-187. https://doi. org/10.1016/j.scienta.2007.03.004.

IPCC (2013). Climate Change 2013: The Physical Science Basis. Contribution of Working Group I to the Fifth Assessment Report of the Intergovernmental Panel on Climate Change, T.F. Stocker, D. Qin, G.-K. Plattner, M. Tignor, S.K. Allen, J. Boschung, A. Nauels, Y. Xia, V. Bex, and P.M. Midgley, eds (Cambridge, U.K. and New York, NY, USA: Cambridge University Press), 1535 pp. https://doi.org/10.1017/ CB09781107415324.

Körner, O., and Challa, H. (2003). Design and improved temperature integration concept in greenhouse cultivation. Comp. Electr. Agric. 39, 39-59. https://doi.org/10.1016/S0168-1699(03)00006-1.

Lee, S.D., Kim, S.J., Jung, S.I., Son, K.-C., and Kays, S.J. (2006). Diurnal $\mathrm{CO}_{2}$ assimilation patterns in nine species of CAM-type succulent plants. HortScience 41, 1373-1376.

Lund, J.B., Andreassen, A., Ottosen, C.-O., and Aaslyng, J.M. (2006). Effect of dynamic climate on energy consumption and production of Hibiscus rosa-sinensis L. in greenhouses. HortScience 41, 384-388.

Lüttge, U. (2004). Ecophysiology of crassulacean acid metabolism (CAM). Ann. Bot. 93, 629-652. https://doi.org/10.1093/aob/ mch087.

Mortensen, L.M. (1983). Growth responses of some greenhouse plants to environment. XII. Effect of $\mathrm{CO}_{2}$ and light on photosynthesis and growth of Sainpaulia ionantha, Kalanchoe blossfeldiana and Nephrolepis exaltata. Meld. Norg. Landbr. Høgsk. 62(16), 1-16.

Mortensen, L.M. (1994). Effect of day/night temperature variations on growth, morphogenesis, and flowering of Kalanchoe blossfeldiana v. Poelln. at different $\mathrm{CO}_{2}$ concentrations, daylengths and photon flux densities. Sci. Hortic. 59, 233-241. https://doi.org/10.1016/03044238(94)90016-7.

Mortensen, L.M. (1995). Diurnal carbon dioxide exchange rates of greenhouse roses under artificial light as compared with daylight conditions in summer. Acta Agric. Scand., Sect. B, Soil and Plant Sci. $45,148-152$.

Mortensen, L.M. (2000). Effects of air humidity on growth, flowering, keeping quality and water relations of four short-day greenhouse species. Sci. Hortic. 86, 299-310. https://doi.org/10.1016/S03044238(00)00155-2.

Mortensen, L.M. (2014). The effect of wide-range photosynthetic active radiations on photosynthesis, growth and flowering of Rosa sp. and Kalanchoe blossfeldiana. Amer. J. Plant Sci. 5, 1489-1498. https://doi.org/10.4236/ajps.2014.511164.

Mortensen, L.M., and Gislerød, H.R. (2016). Fotosyntese hos plantebestander av Argyranthemum frutescens under gode dagslysforhold ved varierende dag/natt-temperatur og ulike $\mathrm{CO}_{2}$ konsentrasjoner. Gartneryrket 10/2016, 33-35 (in Norwegian).

Pagter, M., Petersen, K.K., and Kjaer, K.H. (2013). Direct and indirect effects of shoot- and/or root-chilling stress on growth, photosynthesis, and osmotic root water uptake in Kalanchoe blossfeldiana Poelln. 'Molly'. J. Hort. Sci. and Biotechnol. 88, 571-579. https://doi.org/10.1080/14620316.2013.11513008.

Pinker, R.T., Sun, D., Miller, M., and Robinson, G.J. (2007). Diurnal cycle of land surface temperature in a desert encroachment zone as observed from satellites. Geophys. Re. Letters 34(11). https://doi. org/10.1029/2007GL030186.

Queiroz, O., and Brulfert, J. (1982). Photoperiod-controlled induction and enhancement of seasonal adaption to drought. In Crassulacean Acid Metabolism, I.P. Tings, and M. Gibbs, eds (Rockville: Am. Soc. Plant Physiol.), p. 208-230.

Rascher, U., Blasius, B., Beck, F., and Lüttge, U. (1998). Temperature profiles for the expression of endogenous rhythmicity and arrhythmicity of $\mathrm{CO}_{2}$ exchange in CAM plant Kalanchoe daigremontiana can be shifted by slow temperature changes. Planta 207, 76-82. https://doi.org/10.1007/s004250050457.

Rijsdijk, A.A., and Vogelezang, J.V.M. (2000). Temperature integration on a 24-hour base: a more efficient climate control strategy. Acta Hortic. 519, 163-169. https://doi.org/10.17660/ ActaHortic.2000.519.16.

Taybi, T., Sotta, B., Gehrig, H., Guclu, S., Kluge, M., and Brulfert, J. (1995). Differential-effects of abscisic-acid on phosphoenolpyruvate carboxylase and CAM operation in Kalanchoe blossfeldiana. Botanica Acta 108, 240-246. https://doi.org/10.1111/j.1438-8677.1995. tb00856.x.

Winter, K., and Holtum, J.A.M. (2014). Facultative crassulacean acid metabolism (CAM) plants: powerful tools for unravelling the functional elements of CAM photosynthesis. J. Exp. Botany 65, 34253441. https://doi.org/10.1093/jxb/eru063.

Yamori, W., Hikosaka, K., and Way, D.A. (2014). Temperature response of photosynthesis in $\mathrm{C}_{3}, \mathrm{C}_{4}$, and CAM plants: temperature acclimation and temperature adaptation. Photosynth. Res. 119, 101117. https://doi.org/10.1007/s11120-013-9874-6.

Received: Mar. 24, 2017

Accepted: Nov. 14, 2017

Addresses of authors:

Leiv M. Mortensen* and Hans R. Gislerød

Department of Plant Sciences, Faculty of Biosciences, The Norwegian University of Life Sciences, NO-1432 Ås, Norway

*Corresponding author; E-mail: leiv.mortensen@nmbu.no 